\title{
Flood precaution and coping with floods of companies in Germany
}

\author{
H. Kreibich, I. Seifert, A. H. Thieken \& B. Merz \\ Section Engineering Hydrology, GeoForschungsZentrum Potsdam, \\ Potsdam, Germany
}

\begin{abstract}
During August 2002 and again in April 2006 the Elbe catchment was hit by floods. The flood in 2002 was an extreme event, e.g. with a return period of 150 years at the Dresden gauge. In comparison, the 2006 flood had only a return period of about 15 years at Dresden. This special situation enables a comparison of the preparedness of companies in the flood endangered federal state of Saxony after a long period of relatively low flood discharges and in 2006 just a few years after a severe flood event. Before August 2002, the flood risk awareness and flood preparedness of companies in Saxony was low. Only $25 \%$ of the companies had flood experience before August 2002 and for instance, only 12\% of the companies had used their flood prone stories and areas in a flood adapted way. After 2002, many companies were motivated to undertake precautionary measures. On average, the percentage of companies which had undertaken different building precautionary measures was doubled in 2006. Additionally, the percentage of companies which had undertaken emergency measures before and during the flood events has increased from $67 \%$ in 2002 to $91 \%$ in 2006. It is an important challenge for the future to keep preparedness at a high level also without recurrent flood experiences.
\end{abstract}

Keywords: emergency measures, preparedness, precautionary measures.

\section{Introduction}

In August 2002 a severe flood event hit Germany, Austria, the Czech Republic and Slovakia along the rivers Elbe, Danube and some of their tributaries. Return periods even exceeded 500 years at some tributaries of the Elbe and the return period along the Elbe varied between 150 years at the city of Dresden (Upper 
Elbe) and 25 years at the Lower Elbe near Hamburg [1-3]. In Germany, 21 people were killed and substantial parts of the infrastructure were destroyed. The estimated costs amounted to 11.6 billion $€$ for Germany alone [4]. The most affected German federal state was Saxony, where the total flood damage amounted to 8.7 billion $€[2,5]$. The winter of $2005 / 2006$ was exceptionally rich in snow. In March 2006, in the upper Elbe catchment in the Czech Republic, the amount of water stored as snow was about 2.4 billion $\mathrm{m}^{3}$ [6]. End of March, temperatures rose rapidly to $5-15^{\circ} \mathrm{C}$ leading to a complete snowmelt within one week also in the upper parts of the middle hills [7]. Due to several westerly cyclones snowmelt was accompanied by heavy rainfall in the whole catchment area upstream of the city of Dresden and led to a significant increase in the water levels in the Vltava- and Elbe-catchments. At the Dresden gauge, the water level of the Elbe rose to a maximum of $7.49 \mathrm{~m} \mathrm{[6]} \mathrm{corresponding} \mathrm{to} \mathrm{a} \mathrm{return} \mathrm{period} \mathrm{of}$ 15 years [8].

In the case of floods occurring in the same region just a few years after another, this significantly influences the flood experience of people and companies. In regions where no significant flood had occurred for decades, which was the case at the River Elbe during the second half of the 20th century, flood experience and preparedness is low $[9,10]$. Cases like the Meuse floods in 1993 and 1995, where the severity of the second flood was comparable to that of the first one, show, that better preparedness can result in significantly lower damage of the second flood [11]. To improve the flood management of companies, a comprehensive analysis of the precautionary measures taken in advance and the ability to cope with the actual flood should be undertaken in the aftermath of each flood event. However, only limited data about companies' flood risk and their management are available. This lack of information was already described by Ramirez et al. [12] in 1988, but the situation has not changed much since then. Only a few studies deal quantitatively with the measures companies can undertake to reduce their flood losses [13-15].

The purpose of the paper is to compare the preparedness of companies in the federal state of Saxony in 2002 after a long period of relatively low floods and in 2006 just a few years after a severe flood event.

\section{Data and methods}

Two surveys among flood-affected companies in Germany were undertaken in October 2003/May 2004 and October 2006. On the basis of information obtained from the affected communities and districts, from reports and media coverage as well as from an intersection of road- and address information with satellite-based flood masks (DLR/ZKI personal communication (http://www.zki.caf.dlr.de/ applications/2006/germany/136_de.html), Bayerisches Landesamt für Umwelt, personal communication (http://www.hnd.bayern.de/)) lists of affected streets were comprised. With the help of the telephone directory (yellow pages) sitespecific random samples of companies (i.e. production sites) were generated. After the flood in 2002, 415 interviews were completed, all in the federal state of Saxony. In October 2006, 227 interviews were completed with 23 companies 
affected in 2006 in Saxony. A new standard questionnaire was set up for the investigation in 2003/2004 and was again used with slight improvements in 2006. The questionnaire addressed the following topics: characteristics of the company, flood characteristics, flood warning, emergency measures, clean-up, characteristics of and damage to the building(s), characteristics of and damage to contents, interruption and constraints to business, recovery, preparedness, flood experience and awareness and is described in detail in [10]. The computer-aided telephone interviews were undertaken with the VOXCO software package by the SOKO-Institute for Social Research and Communication (www.soko-institut.de), Bielefeld, Germany. The person who had the best knowledge about flood damage to the company was always questioned. A detailed description of the survey after the 2002 flood is published in [10].

\section{Results and discussion}

\subsection{Risk awareness}

The companies affected by the 2002 flood in Saxony had a low risk awareness and were not well prepared. Only $25 \%$ of the companies had flood experience before 2002 and the last experienced flood was on average 39 years ago (Table 1). The floods most often mentioned, when asked about the last experienced flood event, were the floods in July 1954 along the Elbe and its leftsided tributaries, in July 1957, e.g. along the Gottleuba and Weißeritz rivers, and in July 1958, e.g. along the Zschopau and Mulde rivers. Descriptions of these flood events have been published by Pohl [16]. From the companies without flood experience, only $13 \%$ knew, that their company is located in a flood prone area. The situation was significantly different in 2006: In this data set $90 \%$ of the interviewed companies had flood experience which was on average 4 years ago. For most companies (74\%) the last experienced flood was the August 2002 flood. From the two remaining companies without flood experience, one knew that their company is located in a flood prone area, the other one didn't know.

Table 1: $\quad$ State of flood risk awareness in 2002 and 2006 (interviewed companies after $2002 \mathrm{n}=415$, after $2006 \mathrm{n}=23$ ).

\begin{tabular}{lcc}
\hline & 2002 & 2006 \\
\hline Percentage of companies with flood-experience & $25 \%$ & $90 \%$ \\
Average time since last experienced flood [years] & 39 & 4 \\
Percentage of companies without flood experience & $13 \%$ & $50 \%$ \\
who knew that they are located in a flood prone area & & \\
\hline
\end{tabular}

\subsection{Precautionary measures}

Before the August 2002 flood event, only 12\% of the companies had used their flood prone stories and areas in an adapted way, $8 \%$ had located utilities, sensitive items and equipment in upper stories, $6 \%$ had a flood-adapted building structure and also 6\% had water barriers available (Fig. 1). More companies for 
which these measures are relevant, had stored hazardous substances like chemicals in upper stories (23\%), had a flood proofed air conditioning and/or exhaust-air vent $(32 \%)$ and had flood proofed tanks, silos and other storage containers $(41 \%)$. This might be due to laws and regulations like the statutory order on hazardous incidents. On average, the percentage of companies which had undertaken these measures before the flood in 2006 had doubled, but there are large differences between the measures. The highest increase in popularity from $8 \%$ to $55 \%$, was observed for locating utilities, sensitive items and equipment in upper stories (Fig. 1). The smallest increase, from $32 \%$ to $40 \%$ was in the percentage of companies which had a flood proofed air conditioning and/or exhaust-air vent. The percentage of companies which had flood proofed tanks, silos and other storage containers had decreased slightly from $41 \%$ to $33 \%$. A comprehensive description of efficient building precautionary measures, especially water barrier systems, has been published by Bowker [17]. Detailed investigations of the mitigating effects of the different building precautionary measures revealed that most measures had led to a reduction in mean building damage and all measures had led to a reduction in median building damage to companies during the 2002 flood. But differences were not significant, most likely due to the heterogeneity of the companies and the small sample size [15]. However, the ICPR shows that during less severe floods, building precautionary measures have a significantly higher damage reduction potential [14]. Especially, when contamination can be prevented a significant reduction of flood losses is possible. For example, during the "Pentecost Flood" in May 1999 in the south of Germany, in the region of Kelheim in Bavaria, the mean damage to residential buildings amounted to $15,622 €$, with additional oil contamination the mean damage increased to $52,886 €[18]$.

$30 \%$ of the companies in Saxony were insured against flood losses (Fig. 1), which is for historical reasons considerably higher than the German average. According to information from the Federation of German Insurance Industry (Gesamtverband der Deutschen Versicherungswirtschaft - GDV, pers. comm.) in the elementary damage sector there was an insurance density of $<1 \%$ for companies in Germany. In the federal states in eastern Germany the density of insurances against damage due to natural hazards is significantly higher, since flood losses were included in common insurance contracts in the former German Democratic Republic (GDR). And a lot of contracts have not changed until 2002 [15]. The fraction of insured companies has increased until 2006, when $43 \%$ of the interviewed companies which could get an insurance were insured against flood losses. 9 companies stated, that their company is unable to get a flood insurance. This might be due to the increased efforts insurance companies put into risk assessments after 2002 leading to increasing difficulties to sign an insurance contract for flood endangered companies [4].

Emergency plans were available more than twice as often as emergency exercises had been undertaken (Fig. 1). In August 2002, 10\% of the companies had emergency plans available, only $4 \%$ of the companies had undertaken emergency exercises before. Both measures increased in popularity but the relation between both remained similar. In April 2006, 30\% of the companies 
had emergency plans available and $13 \%$ of the companies had undertaken emergency exercises before. It can be speculated that the popularity of plans in contrast to exercises might be due to the necessity of business interruptions during the time when exercises are undertaken. However, the two measures should not be viewed separately, since emergency plans that have not been tested during emergency exercises may be ineffective.

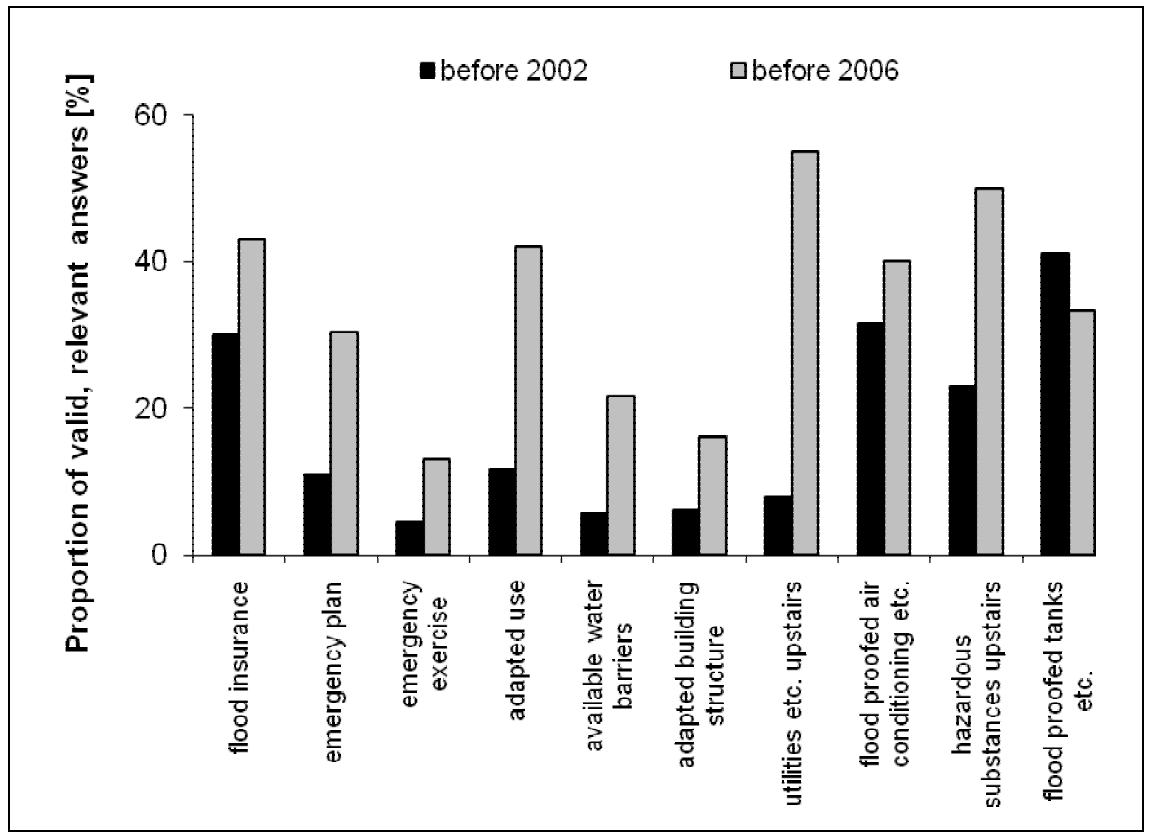

Figure 1: Proportion of companies in Saxony who had undertaken measures of precaution before the flood in 2002 (depending on the measure: $\mathrm{n}=263-415$ ) and before the flood in 2006 (depending on the measure: $\mathrm{n}=6-23$ ).

\subsection{Emergency measures}

The main aim of emergency measures is the safeguarding of equipment, goods, products or stock, which might be achieved by moving them to flood save areas or by using water barriers to prevent the water from entering the building. The percentage of companies that undertook emergency measures, the average time spent for emergency measures and the resulting costs increased a lot from the situation during the 2002 flood in comparison with the 2006 flood (Table 3). Only the average number of people involved was little bit lower in 2006 in comparison with 2002 (Table 3). This is in accordance with previous findings, that mainly relatively recent flood experience supports effective emergency measures $[10,19,20]$.

It is difficult to make generalizations about the positive effects of emergency measures, since they depend on the intensity of the flood event. However, the 
ICPR [14] presumes a 50-75\% reduction of damage due to emergency measures in industry and trade. During the 2002 flood event, the comparison of damage to goods, products or stock of companies that had successfully undertaken emergency measures with the other companies revealed a significant, average damage mitigation of $52 \%$ [10]. Successfully saving the equipment led to a significant average reduction of damage to equipment by $28 \%$ [10].

Table 2: $\quad$ Effort for emergency measures undertaken by the interviewed companies $(2002 \mathrm{n}=415,2006 \mathrm{n}=23)$.

\begin{tabular}{lcc}
\hline & 2002 & 2006 \\
\hline $\begin{array}{l}\text { Percentage of companies which had undertaken } \\
\text { emergency measures [\%] }\end{array}$ & 67 & 91 \\
$\begin{array}{l}\text { Average number of people involved in emergency } \\
\text { measures }\end{array}$ & 16 & 11 \\
$\begin{array}{l}\text { Average time spent on emergency measures [h] } \\
\text { Average cost of emergency measures [1000 €] }\end{array}$ & 13 & 40 \\
\hline
\end{tabular}

\section{Conclusions}

Companies in Saxony were badly prepared for the extreme flood in August 2002. Risk awareness had faded after a long period of low flood discharges. However, companies flood preparedness and precaution improved considerably after the flood in 2002. This case study exemplifies the negative consequences of faded risk awareness on the one hand and the improvements in flood preparedness right after a flood event on the other hand. To keep the awareness over time, it is recommended to make better use of the past flood experience. For example, it seems to be helpful to carry out regular information gatherings at which companies are informed about precautionary measures, etc. Emergency plans have to be updated and exercises undertaken regularly. A standard hazard and risk mapping system including extreme events as well as an uniform strategy at all planning levels and for all states of Germany is needed [21]. Measures with long-lasting effects like building precautionary measures are advantageous, especially if the technique is robust and still able to function in decades. However, it is an important challenge for the future to keep preparedness at a high level also without recurrent flood experiences.

\section{References}

[1] Ulbrich, U., T. Brücher, A.H. Fink, G.C. Leckebusch, A. Krüger, J.G. Pinto (2003): The central European floods of August 2002: Part 1 - Rainfall periods and flood development. Weather 58, 371-377.

[2] IKSE (Internationale Kommission zum Schutz der Elbe) (2004): Dokumentation des Hochwassers vom August 2002 im Einzugsgebiet der Elbe. IKSE, Magdeburg. 
[3] Engel, H. (2004): The flood event 2002 in the Elbe river basin causes of the flood, its course, statistical assessment and flood damages. Houille Blanche 6, 33-36.

[4] Thieken A.H., T. Petrow, H. Kreibich, B. Merz (2006): Insurability and mitigation of flood losses in private households in Germany. Risk Analysis 26(2), 383-395.

[5] SSK (Sächsische Staatskanzlei) (2004): Tillich: Die Sachsen haben den Wiederaufbau weitgehend bewältigt. Press release at 12.08.2004, SSK, Dresden.

[6] Korndörfer C., Rümpel, J.O. Seifert, Kroll, Grebedünkel, Jakob, Frenzel, Ullrich (2006): Bericht zum Frühjahrshochwasser 2006. Report of the Umweltamt Dresden, Dresden, Germany.

[7] BfG (Bundesanstalt für Gewässerkunde) (2006): Das Hochwasser der Elbe im Frühjahr 2006. BfG-1514, Koblenz, Germany.

[8] Kreibich, H., A.H. Thieken (2008): Coping with floods in the city of Dresden, Germany. Natural Hazards DOI 10.1007/s11069-007-9200-8.

[9] Kreibich, H., A.H. Thieken, T. Petrow, M. Müller, B. Merz (2005): Flood loss reduction of private households due to building precautionary measures - Lessons Learned from the Elbe flood in August 2002. NHESS 5: 117-126.

[10] Kreibich, H., M. Müller, A.H. Thieken, B. Merz (2007): Flood precaution of companies and their ability to cope with the flood in August 2002 in Saxony, Germany. Water Res R 43, W03408, doi:10.1029/2005WR004691

[11] Wind, H.G., T.M. Nierop, C.J. de Blois, J.L. de Kok (1999) Analysis of flood damages from the 1993 and 1995 Meuse floods. Water Res R 35(11), 3459-3465.

[12] Ramirez, J., W.L. Adamowicz, K.W. Easter, T. Graham-Tomasi (1988): Ex Post Analysis of Flood Control: Benefit-Cost Analysis and the Value of Information. Water Res R 24(8), 1397-1405.

[13] Smith, D. I. (1981): Actual and potential flood damage: a case study for urban Lismore, NSW, Australia. Appl Geography 1, 31-39.

[14] ICPR (International Commission for the Protection of the Rhine) (2002): Non Structural Flood Plain Management - Measures and their Effectiveness. ICPR, Koblenz.

[15] Kreibich, H., A.H. Thieken, M. Müller, B. Merz (2005): Precautionary measures reduce flood losses of households and companies - Insights from the 2002 flood in Saxony, Germany. In: van Alphen, J., E. van Beek, M. Taal (eds.): Floods, from Defence to Management. Taylor \& Francis Group, London, 851-859.

[16] Pohl, R. (2004): Historische Hochwasser aus dem Erzgebirge. Wasserbauliche Mitteilungen 28, 237 pp., Technische Universität Dresden, Dresden.

[17] Bowker, P. (2002): Making properties more resistant to floods. P I Civ E M 151(3), 197-205.

[18] Deutsche Rückversicherung (1999): Das Pfingsthochwasser im Mai 1999. Deutsche Rückversicherung, Düsseldorf. 
302 Flood Recovery, Innovation and Response I

[19] Burn, D.H. (1999): Perception of flood risk: A case study of the Red River flood of 1997. Water Res R 35(11), 3451-3458.

[20] Yeo, S.W. (2002): Flooding in Australia: A Review of Events in 1998. Natural Hazards 25, 177-191.

[21] Petrow, T., A.H. Thieken, H. Kreibich, C.H. Bahlburg, B. Merz (2006): Improvements on Flood Alleviation in Germany: Lessons Learned from the Elbe Flood in August 2002. Environ Manage 38, 717-732. 